\title{
An unexpected Prins desymmetrisation reaction driven by silyl migration
}

\author{
Michael Butters, ${ }^{\text {b }}$ Mark C Elliott, ${ }^{\mathrm{a}, *}$ and Joseph T. Hill-Cousins ${ }^{\mathrm{a}}$ \\ ${ }^{a}$ School of Chemistry, Cardiff University, Main College Building, Park Place, \\ Cardiff, CF10 3AT, UK \\ ${ }^{b}$ AstraZeneca Process R\&D Avlon/Charnwood, AvlonWorks, Severn Road, Hallen, \\ Bristol, BS10 7ZE, UK \\ E-mail:elliottmc@cardiff.ac.uk
}

Dedicated to Professor Keith Smith on the occasion of his $65^{\text {th }}$ birthday

\begin{abstract}
Prins desymmetrisation reactions of cyclohexa-1,4-diene derivatives have been investigated as a route to the core of the cladiellin diterpenes. During the course of this work, we observed the formation of a partially-reduced benzofuran 18, which is clearly derived from oxocarbenium ion 21. This can only be rationalised by an unexpected primary to secondary silyl group migration.
\end{abstract}

Keywords: Prins reaction, tetrahydrofuran, heterocycle, diterpene, natural product

\section{Introduction}

We have recently reported model studies for the Prins desymmetrisation of cyclohexa-1,4-dienes to give systems related to the cladiellin diterpenes. ${ }^{1}$ In our initial work, compound $\mathbf{1}$ underwent a rather dramatic transformation into compound $\mathbf{2}$ by way of formation and reaction of an oxocarbenium ion followed by rearrangement. In this way, the core functionality and stereochemistry of the cladiellin diterpenes, for example 7-deacetoxyalcyonin acetate $(\mathbf{3})^{2}$ was rapidly established (Scheme 1). 


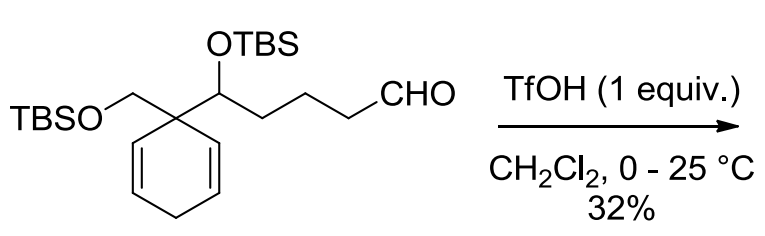

1

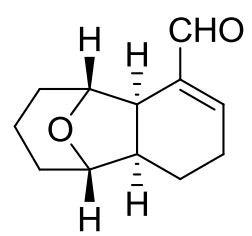

2

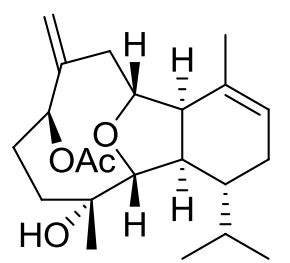

3, 7-deacetoxyalcyonin acetate

\section{Scheme 1}

This reaction involves the double-deprotection of compound $\mathbf{1}$ to give intermediate $\mathbf{4}$, followed by formation of oxocarbenium ion 5 , cyclisation to give $\mathbf{6}$ which rearranges to give 7 and deprotonation/tautomerisation to give the product $\mathbf{2}$ (Scheme 2).<smiles>CC(C)(C)OCC1(C([O+])[Se-])C=CCC=C1</smiles>

1<smiles>CC(C)C(C)C(O)CCCCC1(CO)C=CCC=C1</smiles>

4<smiles>OCC1(C2C=CCCC2)C=CCC=C1</smiles>

5

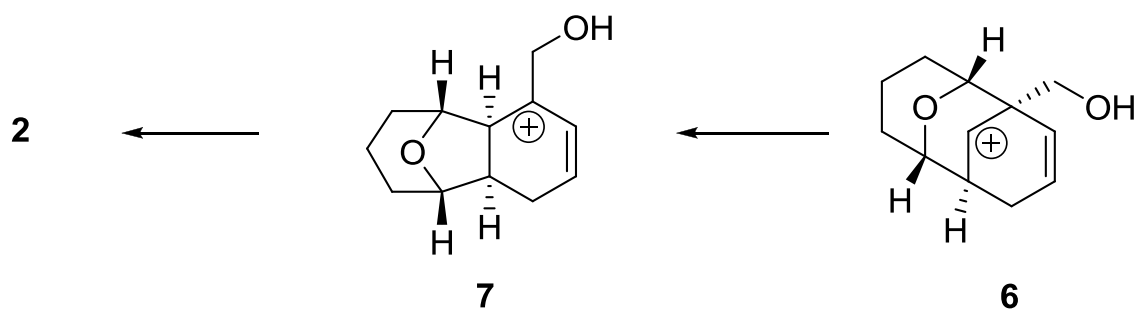

\section{Scheme 2}

In seeking to extend these studies, we elected to fuse an additional ring onto the precursor as shown in Scheme 3. While the fusion of an aromatic ring is appropriate for such a study, we envisage that eventually this will be replaced with a system that can be cleaved to give the complete cladiellin core. It was therefore envisaged that the Prins desymmetrisation of compound $\mathbf{8}$ would give rise to compound $\mathbf{9}$. 
<smiles>O=Cc1ccccc1CC(O)C1(COC(F)(F)F)C=CCC=C1</smiles>

8
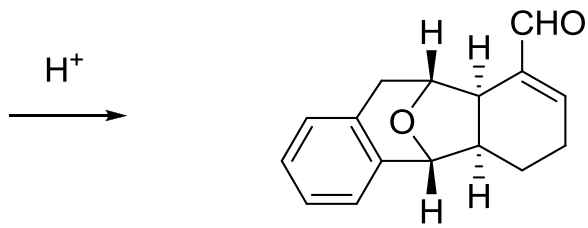

9

Scheme 3

\section{Results and Discussion}

It was envisaged that the key precursor 12 would be accessible by formation of an organolithium compound from $\mathbf{1 1}$ and then reaction with the epoxide $\mathbf{1 0}$ (Scheme 4).

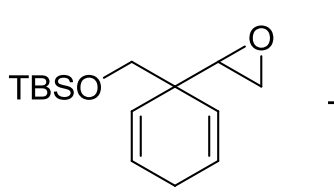

10

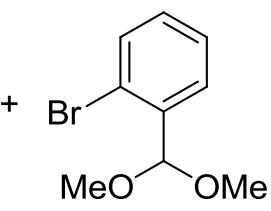

11

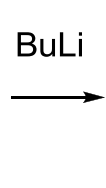

\section{Scheme 4}

Compound 11 was prepared according to a literature method. ${ }^{3}$ Compound $\mathbf{1 0}$ was prepared as shown in Scheme 5. Birch reduction of benzoic acid followed by esterification gave compound 13. Deprotonation and acylation with methyl chloroformate was followed by lithium aluminium hydride reduction to give diol 15. Mono-silylation and Swern oxidation then gave aldehyde 17. Addition of bromomethyllithium to the aldehyde was rather troublesome. With an excess of bromomethyllithium complex mixtures of products were obtained. Therefore it was better to use only a slight excess. Under these conditions the reaction did not proceed to completion, but the unreacted aldehyde was readily removed by treatment of the crude reaction mixture with sodium borohydride prior to chromatography. This gave the desired epoxide $\mathbf{1 0}$ in satisfactory yield.

Lithiation of compound 11 with $t$-BuLi for 10 minutes at $-78{ }^{\circ} \mathrm{C}$ prior to addition of epoxide 10 initially appeared to have been successful. Purification gave a product in which the acetal had been retained along with a 1,2-disubstituted benzene ring, and that the epoxide had been opened. This was therefore subjected to the conditions of the Prins desymmetrisation (Scheme 6). It rapidly became clear that the product of this two-step process was the partiallyreduced benzofuran $\mathbf{1 8}$ rather than the desired product. The structural assignment of compound 


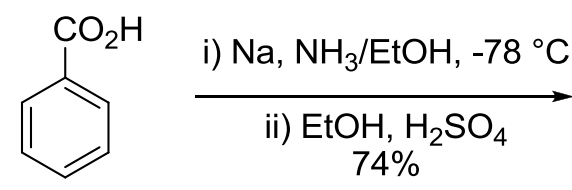

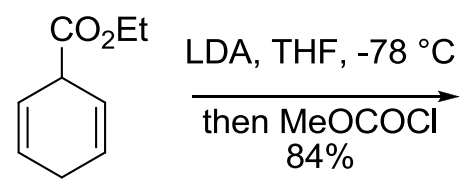

13<smiles>CCOC(=O)C1(C(C)=O)C=CCC=C1</smiles>

14 $\downarrow \begin{aligned} & \mathrm{LiAlH}_{4} \\ & \mathrm{THF}, 2 \mathrm{~h} \\ & 67 \%\end{aligned}$<smiles>O=CC1(CO[R15](F)(F)F)C=CCC=C1</smiles><smiles>CC(C)(C)OCC1(CO)C=CCC=C1</smiles>

16

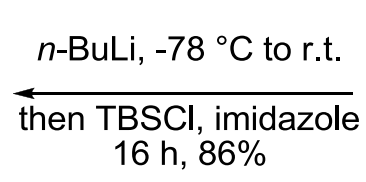

$16 \mathrm{~h}, 86 \%$<smiles>OCC1(CO)C=CCC=C1</smiles>

15
17

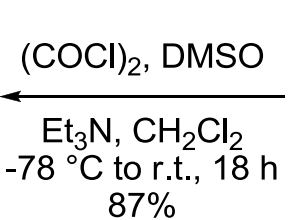
$87 \%$

i) $n$-BuLi, $\mathrm{CH}_{2} \mathrm{Br}_{2}$, THF

$-78{ }^{\circ} \mathrm{C}$ to r.t., $24 \mathrm{~h}$

ii) $\mathrm{NaBH}_{4}, \mathrm{MeOH}, 0^{\circ} \mathrm{C}, 1 \mathrm{~h}$ $38 \%$<smiles>CC(C)(C)OCC1(C2CO2)C=CCC=C1</smiles>

10

\section{Scheme 5}

18 was by no means straightforward. Extensive analysis of ${ }^{1} \mathrm{H}$ and ${ }^{13} \mathrm{C}$ NMR spectroscopic data, and ${ }^{1} \mathrm{H}-{ }^{1} \mathrm{H}$ and ${ }^{1} \mathrm{H}-{ }^{13} \mathrm{C}$ correlation data (COSY, HMBC and HSQC) enabled determination of the carbon-hydrogen framework connectivity. Mass spectrometric studies identified the presence of the two bromine atoms in the compound 18. The stereochemistry of compound $\mathbf{1 8}$ was assigned by analogy with that of related compounds. ${ }^{1 \mathrm{~b}}$

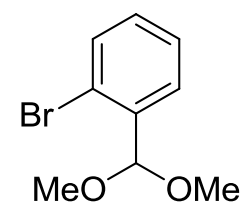

11 i) $t$-BuLi, THF, $-78^{\circ} \mathrm{C}, 10 \mathrm{~min}$ then $10, \mathrm{BF}_{3} . \mathrm{THF}, 1 \mathrm{~h}$

ii) $\mathrm{TfOH}, \mathrm{CH}_{2} \mathrm{Cl}_{2}, 0^{\circ} \mathrm{C}$ to r.t. $29 \%$<smiles>O=C(CBr)C1=CCC[C@@H]2[C@@H]1CO[C@@H]2c1ccccc1Br</smiles>

18

\section{Scheme 6}


In a previous study, we reported the formation of ketones during Prins desymmetrisation reactions. ${ }^{1 \mathrm{~b}}$ These arise by protonation of an acetal $\mathbf{1 9}$ on the more hindered oxygen followed by the Prins reaction, and compounds 20 were invariably the minor products (Scheme 7). In this case compound $\mathbf{1 4}$ was the only product formed, which suggests that if an acetal such as $\mathbf{1 9}$ is formed, it is opened regioselectively but in the "wrong" direction. This seems rather unlikely.<smiles>[R]C1OCC2(C=CCC=C2)C([R])O1</smiles>

19

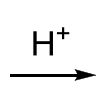<smiles>[R]C1OCC2(C=CCC=C2)C([R])O1</smiles><smiles>CCCCCCCC</smiles><smiles>[R]C(=O)C1=CCC[C@@H]2CO[C@@H]([R2])[C@H]12</smiles>

20

\section{Scheme 7}

However, since the structure of compound $\mathbf{1 8}$ is secure, it is clear that it must be formed from oxocarbenium ion 21 ( $\mathrm{R}=\mathrm{H}$ or TBS). Since it is unlikely that opening of an acetal forms this intermediate, the most likely explanation is opening of epoxide $\mathbf{1 0}$ by bromide derived from the partial lithiation of compound $\mathbf{1 1}$.

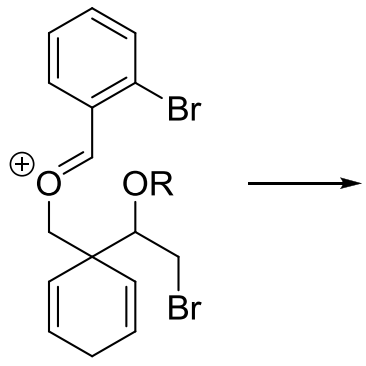

21<smiles>O=C(CBr)C1=CCC[C@@H]2[C@@H]1CO[C@@H]2c1ccccc1Br</smiles>

18

\section{Scheme 8}

In order to investigate this process further, the coupling of compounds $\mathbf{1 0}$ and $\mathbf{1 1}$ was repeated. Extensive chromatography led to the isolation of an epoxide-opening product that lacked the aromatic ring (Scheme 9). This was assigned structure $\mathbf{2 2}$ or $\mathbf{2 3}$, although we could not a priori deduce the location of the silyl group. Examination of the spectra from the previous coupling reaction showed that the same epoxide-opening product was present. As a result of the subsequent formation of compound 18, it seems overwhelmingly likely that the structure is $\mathbf{2 3}$ and not 22, so that a silyl migration has taken place during the epoxide-opening. 
<smiles>COC(OC)c1ccccc1Br</smiles>

11

$$
\begin{gathered}
\underset{t \text {-BuLi, THF, }-78{ }^{\circ} \mathrm{C}, 10 \mathrm{~min}}{\longrightarrow} \\
\text { then } 10, \mathrm{BF}_{3} \text { THF, } 1 \mathrm{~h} \\
64 \%
\end{gathered}
$$<smiles>CC(C)(C)OCC1(C(O)CBr)C=CCC=C1</smiles>

22<smiles>OCC1(C(Br)CBr)C=CCC=C1</smiles>

23

Scheme 9

Explaining this apparent silyl migration is not straightforward. While there are many examples of silyl groups migrating from secondary to primary alcohols in the literature, ${ }^{4}$ we could find no examples of primary to secondary migration, and we assume that such a process would be kinetically disfavoured. However, if we assume that the $\mathrm{BF}_{3}$ coordinates to the epoxide oxygen in order to assist the epoxide-opening, we can consider the intermediacy of a hypervalent silicon compound 26a (Scheme 10). The $\mathrm{BF}_{3}$ should then be readily transferred to the lesshindered oxygen which will give intermediate 27 a which should then undergo opening with effective silyl-transfer to give 29a. In fact, this process is very reminiscent of the regioselective opening of the corresponding acetals with Lewis acids. ${ }^{1}$

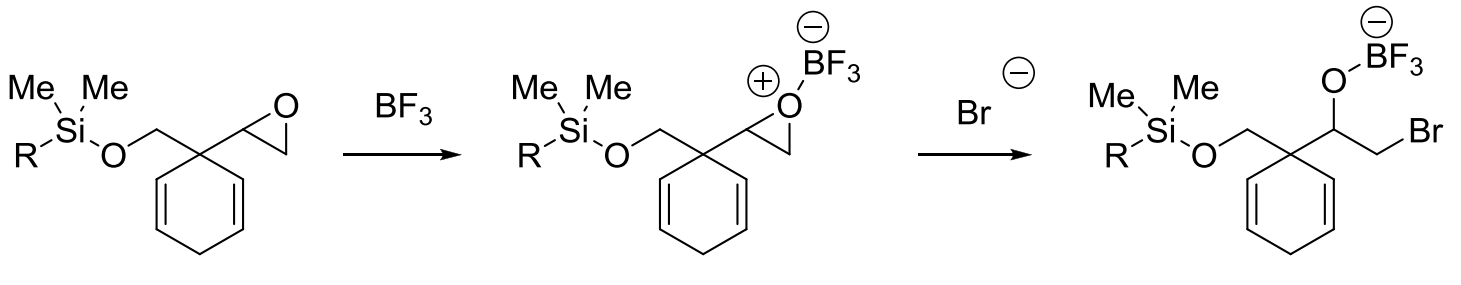

10

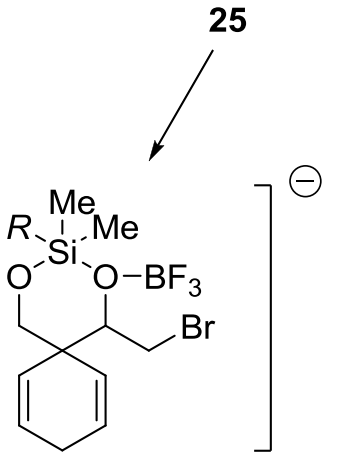

a, $\mathrm{R}=t-\mathrm{Bu}$

b, $\mathrm{R}=\mathrm{Me}$

26

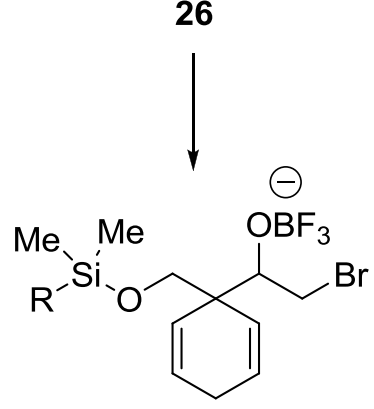

28

Scheme 10 
Density functional theory calculations (Spartan 10, B3LYP 6-31+G*) have provided some insight into this transformation. For simplicity the calculations were carried out with a

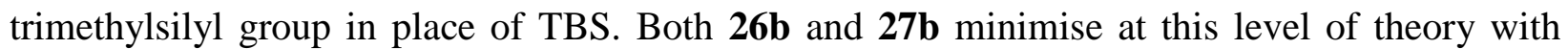
cleavage of a $\mathrm{Si}-\mathrm{O}$ bond, so that it was not possible to obtain minimum energy structures for these intermediates. However, a single-point DFT calculation based on a molecular mechanics minimised structure in each case indicated that $\mathbf{2 7 \mathbf { b }}$ is considerably more stable than $\mathbf{2 6 \mathbf { b }}(235 \mathrm{~kJ}$ $\mathrm{mol}^{-1}$, although since these numbers are not based on optimised structures, they should be interpreted cautiously) (Figure 1). In both cases the $\mathrm{BF}_{3}$ is axial to avoid severe steric interactions with the trimethylsilyl group. However, upon minimisation, the product $\mathbf{2 9 b}$ is more stable than $\mathbf{2 8 b}$ (by $11.6 \mathrm{~kJ} \mathrm{~mol}^{-1}$ ). The lowest energy conformers of these two structures are shown in Figure 2. Therefore, we would tentatively attribute the formation of intermediate $\mathbf{2 9}$ as being due to rapid migration of the $\mathrm{BF}_{3}$ to the less-hindered oxygen.

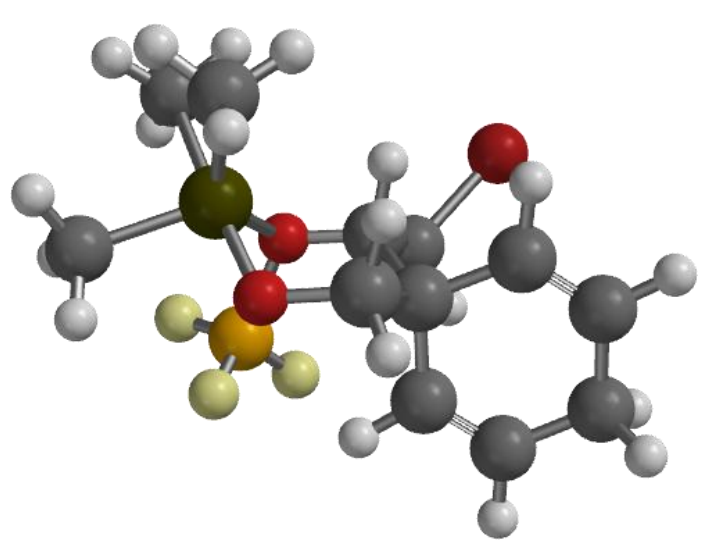

$-3807.72667 \mathrm{H}$

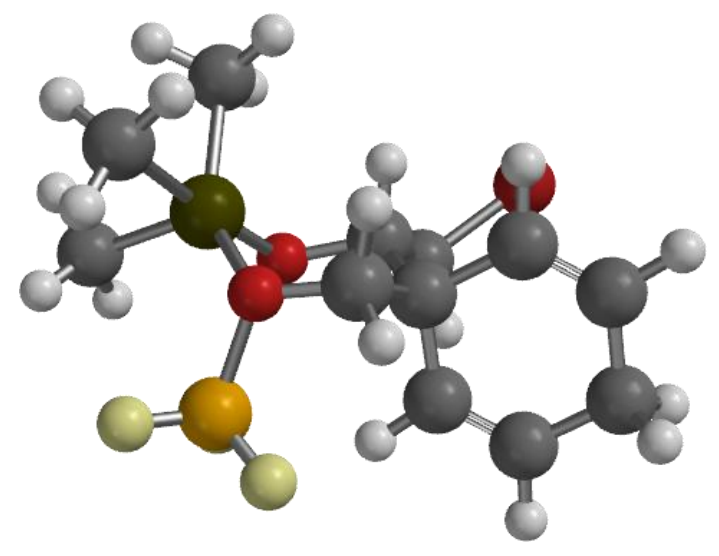

$-3807.74829 \mathrm{H}$

Figure 1. Spartan MMFF minimised structures of $\mathbf{2 6 \mathbf { b }}$ and $\mathbf{2 7} \mathbf{b}$, and single-point DFT (6-31+G*) energies.

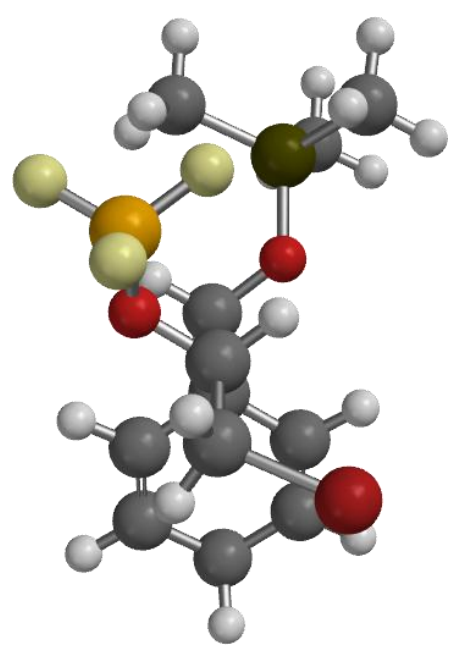

$-3807.90925 \mathrm{H}$

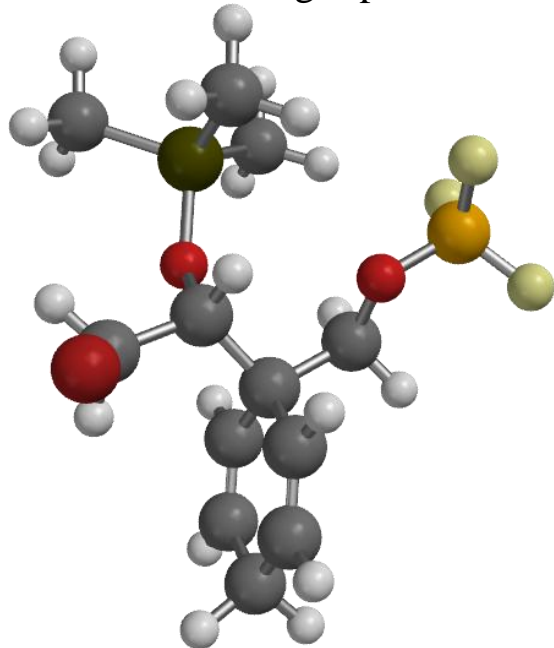

$-3807.90484 \mathrm{H}$

Figure 2. B3LYP $\left(6-31+\mathrm{G}^{*}\right)$ lowest energy conformers of $\mathbf{2 8 b}$ and $\mathbf{2 9 b .}$ 


\section{Conclusions}

The formation of compound $\mathbf{1 8}$ was unanticipated on the basis of our previous work. However, it can be rationalised as a result of an unexpected primary to secondary silyl migration as follows. Metal-halogen exchange on compound $\mathbf{1 1}$ generates bromide. Presumably the organolithium reagent is also formed, but the fate of this species is unclear. Boron trifluoride promotes the opening of epoxide 10 with bromide to generate intermediate 25a, which rearranges under the influence of the boron trifluoride to give the primary alcohol 23. Oxocarbenium ion 21 is then formed by reaction with $\mathbf{1 1}$, and cyclisation of this ion initially gives the secondary carbenium ion $\mathbf{3 0}$ before rearrangement to the more stable allylic carbenium ion 31. Loss of a proton will be followed by hydrolysis and tautomerisation of the silyl enol ether $\mathbf{3 2}$ to ultimately give the observed product 18.<smiles>COC(OC)c1ccccc1Br</smiles>

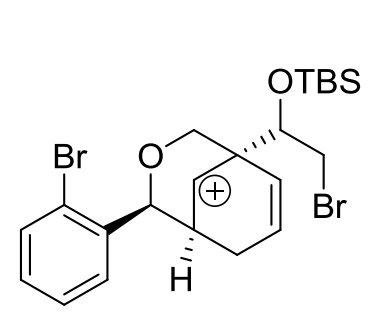

30

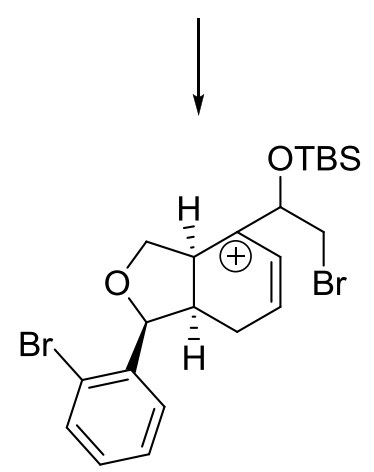

31

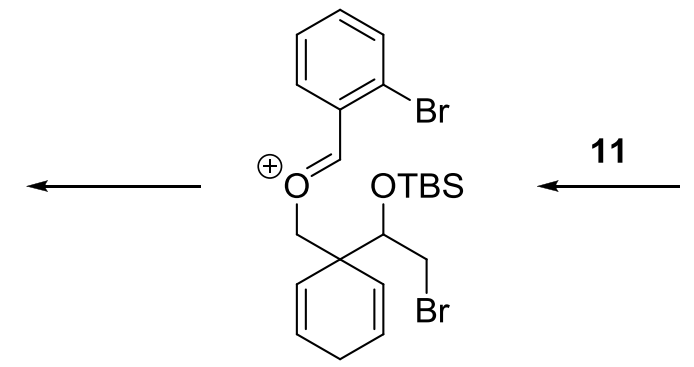

21<smiles>OCC1(C(Br)Br)C=CCC=C1</smiles>

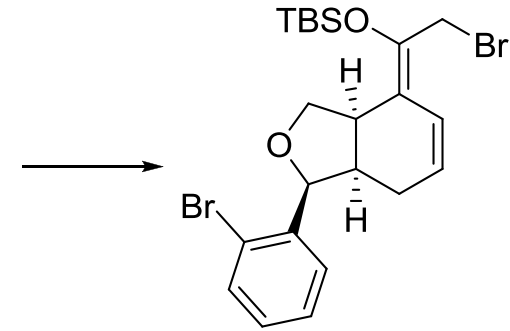

32

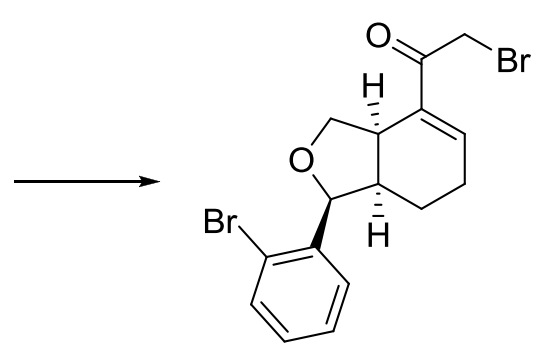

18

Scheme 11 


\section{Experimental Section}

General. Melting points were determined on a Gallenkamp melting point apparatus. Infrared spectra were recorded on a Perkin Elmer 1600 FTIR spectrophotometer. Mass spectra were recorded on a Fisons VG Platform II spectrometer and on a Micromass Q-TOF Micro spectrometer. NMR spectra were recorded on a Bruker DPX 400 spectrometer operating at 400 $\mathrm{MHz}$ for ${ }^{1} \mathrm{H}$ and at $100 \mathrm{MHz}$ for ${ }^{13} \mathrm{C}$ at $25{ }^{\circ} \mathrm{C}$, or on a Bruker Avance 500 spectrometer operating at $500 \mathrm{MHz}$ for ${ }^{1} \mathrm{H}$ and $125 \mathrm{MHz}$ for ${ }^{13} \mathrm{C}$ at $25{ }^{\circ} \mathrm{C}$. All chemical shifts are reported in ppm downfield from TMS. Coupling constants $(J)$ are reported in Hz. Multiplicity in ${ }^{1} \mathrm{H}$ NMR spectroscopy is reported as singlet (s), doublet (d), double doublet (dd), double triplet (dt), double quartet $(\mathrm{dq})$, triplet $(\mathrm{t})$, and multiplet $(\mathrm{m})$. Multiplicity in ${ }^{13} \mathrm{C}$ NMR spectroscopy was obtained using the DEPT pulse sequence. Flash chromatography was performed using Matrex silica 60 35-70 micron. Solvents for moisture-sensitive reactions were dried by distillation; THF over sodium benzophenone ketal and $\mathrm{CH}_{2} \mathrm{Cl}_{2}$ over $\mathrm{CaH}_{2}$. Such reactions were carried out under an atmosphere of nitrogen.

Ethyl cyclohexa-2,5-dienecarboxylate (13). ${ }^{5}$ Sodium metal $(6.22 \mathrm{~g}, 270 \mathrm{mmol})$ was added in portions to a solution of benzoic acid $(10.0 \mathrm{~g}, 81.9 \mathrm{mmol})$ in liquid $\mathrm{NH}_{3}-\mathrm{EtOH}(4: 1,500 \mathrm{ml})$ at $78{ }^{\circ} \mathrm{C}$. After the blue colour had faded, solid $\mathrm{NH}_{4} \mathrm{Cl}(17.5 \mathrm{~g})$ was added and the ammonia was allowed to evaporate. The mixture was then acidified by addition of $2 \mathrm{M} \mathrm{HCl}$ and the aqueous layer extracted with $\mathrm{Et}_{2} \mathrm{O}$. The combined extracts were dried $\left(\mathrm{Na}_{2} \mathrm{SO}_{4}\right)$ before the solvent was removed in vacuo. The residue was re-dissolved in $\mathrm{EtOH}(250 \mathrm{ml})$ and treated with conc. $\mathrm{H}_{2} \mathrm{SO}_{4}$ $(\sim 0.5 \mathrm{ml})$. The resulting solution was allowed to stir at room temperature for $16 \mathrm{~h}$. The solvent was removed in vacuo and the reaction mixture neutralized by addition of saturated aqueous $\mathrm{NaHCO}_{3}$ solution. The aqueous layer was extracted with $\mathrm{Et}_{2} \mathrm{O}$ and the combined extracts dried over $\mathrm{Na}_{2} \mathrm{SO}_{4}$. The solvent was removed in vacuo affording the title compound $13(9.23 \mathrm{~g}, 74 \%)$ as a pure colourless oil. IR: $v_{\max }$ (Nujol): 2981, 2873, 2821, 1735, 1366, 1179, 1034, 942898 , 715 and $668 \mathrm{~cm}^{-1}$. NMR: $\delta_{\mathrm{H}}\left(400 \mathrm{MHz} ; \mathrm{CDCl}_{3}\right): 5.90-5.86(2 \mathrm{H}, \mathrm{m}$, alkene $\mathrm{CH}), 5.84-5.79$ (2 $\mathrm{H}, \mathrm{m}$, alkene $\mathrm{CH}), 4.16\left(2 \mathrm{H}, \mathrm{q}, J=7.1, \mathrm{CH}_{2} \mathrm{O}\right), 3.75-3.68(1 \mathrm{H}$, broad $\mathrm{m}, \mathrm{CH}), 2.71-2.66(2$ $\mathrm{H}$, broad $\left.\mathrm{m}, \mathrm{CH}_{2}\right)$ and $1.27\left(3 \mathrm{H}, \mathrm{t}, J=7.1, \mathrm{CH}_{3}\right) ; \delta_{\mathrm{C}}\left(100 \mathrm{MHz} ; \mathrm{CDCl}_{3}\right): 172.6(\mathrm{C}=\mathrm{O}), 126.3(2$ $\times \mathrm{CH}), 122.2(2 \times \mathrm{CH}), 60.9\left(\mathrm{CH}_{2}\right), 41.7(\mathrm{CH}), 25.8\left(\mathrm{CH}_{2}\right)$ and $14.2\left(\mathrm{CH}_{3}\right)$.

1-Ethyl 1-methyl cyclohexa-2,5-diene-1,1-dicarboxylate (14). $n$-Butyllithium (13.2 ml of a 2.5 $\mathrm{M}$ solution in hexanes, $32.9 \mathrm{mmol}$ ) was added dropwise to a solution of diisopropylamine (4.61 $\mathrm{ml}, 32.9 \mathrm{mmol})$ in THF $(50 \mathrm{ml})$ at $0{ }^{\circ} \mathrm{C}$. The mixture was allowed to stir for 30 minutes at the same temperature before being cooled to $-78{ }^{\circ} \mathrm{C}$. The ester $13(5.01 \mathrm{~g}, 33.0 \mathrm{mmol})$ was added dropwise and the reaction mixture allowed to stir for 30 minutes at $-78{ }^{\circ} \mathrm{C}$ before methyl chloroformate $(2.80 \mathrm{ml}, 36.2 \mathrm{mmol})$ was added. The resulting solution was stirred for a further 15 minutes at $-78{ }^{\circ} \mathrm{C}$ before the reaction was quenched with saturated aqueous $\mathrm{NH}_{4} \mathrm{Cl}$ solution. The mixture was extracted with $\mathrm{Et}_{2} \mathrm{O}$, the combined extracts being dried $\left(\mathrm{Na}_{2} \mathrm{SO}_{4}\right)$ before the solvent was removed in vacuo. Chromatography on silica gel $\left(\mathrm{Et}_{2} \mathrm{O}\right.$ : petroleum ether 1: 19) 
afforded the title compound $\mathbf{1 4}(5.84 \mathrm{~g}, 84 \%)$ as a colourless oil. IR: $v_{\max }$ (neat): 2984, 2956, $1735,1436,1251,1205,1064,1038,860,801,778$ and $704 \mathrm{~cm}^{-1}$. NMR: $\delta_{\mathrm{H}}\left(400 \mathrm{MHz} ; \mathrm{CDCl}_{3}\right)$ : $6.07-6.02$ (2 H, m, alkene $\mathrm{CH}), 5.98$ (2 H, app. dt, $J=10.4,1.8$, alkene $\mathrm{CH}), 4.20$ (2 H, q, $J=$ 7.1, $\left.\mathrm{CH}_{2} \mathrm{O}\right), 3.75\left(3 \mathrm{H}, \mathrm{s}, \mathrm{OCH}_{3}\right), 2.72-2.70\left(2 \mathrm{H}, \mathrm{m}\right.$, ring $\left.\mathrm{CH}_{2}\right)$ and $1.26\left(3 \mathrm{H}, \mathrm{t}, J=7.1, \mathrm{CH}_{3}\right)$; $\delta_{\mathrm{C}}\left(100 \mathrm{MHz} ; \mathrm{CDCl}_{3}\right): 170.3(\mathrm{C}), 169.6(\mathrm{C}), 127.8(2 \times \mathrm{CH}), 122.2(2 \times \mathrm{CH}), 61.9\left(\mathrm{CH}_{2}\right), 55.4$ (C), $52.9\left(\mathrm{CH}_{3}\right), 25.9\left(\mathrm{CH}_{2}\right)$ and $14.0\left(\mathrm{CH}_{3}\right)$.

Cyclohexa-2,5-diene-1,1-diyldimethanol (15). A solution of diester 14 (5.84 g, $27.8 \mathrm{mmol})$ in THF (20 ml) was added slowly to a suspension of $\mathrm{LiAlH}_{4}(2.11 \mathrm{~g}, 55.6 \mathrm{mmol})$ in THF $(60 \mathrm{ml})$. The mixture was allowed to stir at room temperature for $2 \mathrm{~h}$ before being quenched by slow addition of aqueous $2 \mathrm{M} \mathrm{NaOH}$ solution. The solution was dried $\left(\mathrm{Na}_{2} \mathrm{SO}_{4}\right)$, filtered and the solvent removed in vacuo. Chromatography on silica gel (EtOAc: petroleum ether 2: 1) afforded the title compound 15 (2.59 g, 67\%) as a colourless solid, m.p. $82-84^{\circ} \mathrm{C}$. IR: $v_{\max }$ (Nujol): 3399, 2923, 2855, 1633, 1252, 1100, 1023, 984, 940, 898 and $707 \mathrm{~cm}^{-1}$. NMR: $\delta_{\mathrm{H}}(400 \mathrm{MHz}$; $\left.\mathrm{CDCl}_{3}\right): 6.09-6.04(2 \mathrm{H}, \mathrm{m}$, alkene $\mathrm{CH}), 5.60-5.56(2 \mathrm{H}, \mathrm{m}$, alkene $\mathrm{CH}), 3.52(4 \mathrm{H}, \mathrm{s}, 2 \times$ $\left.\mathrm{CH}_{2} \mathrm{O}\right), 2.72\left(2 \mathrm{H}\right.$, app. tt, $J=3.4,2.1$, ring $\left.\mathrm{CH}_{2}\right)$ and $1.69(2 \mathrm{H}$, broad s, $2 \times \mathrm{OH}) ; \delta_{\mathrm{C}}(100 \mathrm{MHz}$; $\left.\mathrm{CDCl}_{3}\right): 128.5(2 \times \mathrm{CH}), 126.9(2 \times \mathrm{CH}), 68.0\left(2 \times \mathrm{CH}_{2}\right), 44.6(\mathrm{C})$ and $26.9\left(\mathrm{CH}_{2}\right)$.

[1-[(tert-Butyldimethylsilyloxy)methyl]cyclohexa-2,5-dienyl]methanol (16). $n$-Butyllithium (2.40 $\mathrm{ml}$ of $2.5 \mathrm{M}$ solution in hexanes, $6.01 \mathrm{mmol}$ ) was added to a solution of diol 15 (886 $\mathrm{mg}$, $6.33 \mathrm{mmol})$ in THF $(15 \mathrm{ml})$ at $-78{ }^{\circ} \mathrm{C}$. The resulting solution was allowed to warm to room temperature over $1 \mathrm{~h}$ before a solution of tert-butyldimethylsilyl chloride ( $859 \mathrm{mg}, 5.70 \mathrm{mmol})$ in THF ( $5 \mathrm{ml}$ ) was added. The reaction mixture was stirred for 30 minutes before imidazole (cat.) was added. The resulting mixture was stirred for $16 \mathrm{~h}$ at room temperature before the reaction was quenched with saturated aqueous $\mathrm{NaHCO}_{3}$ solution. The mixture was extracted with $\mathrm{Et}_{2} \mathrm{O}$, the combined extracts being dried $\left(\mathrm{Na}_{2} \mathrm{SO}_{4}\right)$ before the solvent was removed in vacuo. Chromatography on silica gel (EtOAc: petroleum ether 1: 1) afforded the title compound 16 $(1.38 \mathrm{~g}, 86 \%)$ as a colourless oil. IR: $v_{\max }$ (Neat): 3419, 3028, 2954, 2929, 2885, 2857, 1635, 1471, 1464, 1255, 1084, 1046, 940, 838, 776 and $708 \mathrm{~cm}^{-1}$. NMR: $\delta_{\mathrm{H}}\left(500 \mathrm{MHz} ; \mathrm{CDCl}_{3}\right): 5.94-$ 5.91 ( $2 \mathrm{H}, \mathrm{m}$, alkene $\mathrm{CH}), 5.62$ (2 H, app. dt, $J=10.5,2.0$, alkene $\mathrm{CH}$ ), 3.59 (2 H, s, $\left.\mathrm{CH}_{2} \mathrm{OTBS}\right)$, $3.54\left(2 \mathrm{H}, \mathrm{s}, \mathrm{CH}_{2} \mathrm{OH}\right), 2.70-2.68\left(2 \mathrm{H}, \mathrm{m}\right.$, ring $\left.\mathrm{CH}_{2}\right), 2.17-1.87(1 \mathrm{H}$, broad s, OH), $0.89(9 \mathrm{H}$, $\mathrm{s}, t$-Bu $)$ and $0.04\left(6 \mathrm{H}, \mathrm{s}, 2 \times \mathrm{CH}_{3}\right) ; \delta_{\mathrm{C}}\left(125 \mathrm{MHz} \mathrm{CDCl}_{3}\right): 127.3(2 \times \mathrm{CH}), 127.0(2 \times \mathrm{CH}), 69.7$ $\left(\mathrm{CH}_{2}\right), 69.1\left(\mathrm{CH}_{2}\right), 43.6(\mathrm{C}), 27.1\left(\mathrm{CH}_{2}\right), 25.8\left(3 \times \mathrm{CH}_{3}\right), 18.2(\mathrm{C})$ and -5.6 $\left(2 \times \mathrm{CH}_{3}\right)$. MS-APCI: $\mathrm{m} / \mathrm{z}(\%)=255\left(\mathrm{M}+\mathrm{H}^{+}, 100\right), 237(21), 177(17), 156(7), 130$ (6) and 105 (3). HRMS-APCI: $\mathrm{m} / z$ $[\mathrm{M}+\mathrm{H}]^{+}$calcd for $\mathrm{C}_{14} \mathrm{H}_{27} \mathrm{O}_{2} \mathrm{Si}$ : 255.1780; found: 255.1776.

\section{1-[(tert-Butyldimethylsilyloxy)methyl]cyclohexa-2,5-dienecarbaldehyde $\quad(17){ }^{6} \quad$ Oxalyl} chloride $(0.59 \mathrm{ml}, 6.89 \mathrm{mmol})$ was added dropwise into a solution of DMSO (1.12 $\mathrm{ml}, 15.7$ mmol $)$ in $\mathrm{CH}_{2} \mathrm{Cl}_{2}(20 \mathrm{ml})$ at $-78^{\circ} \mathrm{C}$. The solution was stirred for 10 minutes before the alcohol 16 (499 mg, $1.96 \mathrm{mmol}$ ) was added dropwise. After stirring for a further 10 minutes at $-78{ }^{\circ} \mathrm{C}$, triethylamine $(3.57 \mathrm{ml}, 25.6 \mathrm{mmol})$ was added and the reaction mixture allowed to warm to room temperature over $2 \mathrm{~h}$. The reaction was quenched by pouring into saturated aqueous $\mathrm{NaHCO}_{3}$ solution. The crude product was extracted with $\mathrm{CH}_{2} \mathrm{Cl}_{2}$, the combined extracts being dried 
$\left(\mathrm{Na}_{2} \mathrm{SO}_{4}\right)$ before the solvent was removed in vacuo. Chromatography on silica gel $\left(\mathrm{Et}_{2} \mathrm{O}\right.$ : petroleum ether 1: 49) afforded the title compound $17(429 \mathrm{mg}, 87 \%)$ as a colourless oil. IR: $v_{\max }$ (Neat): 3032, 2955, 2929, 2886, 2857, 1729, 1651, 1634, 1471, 1420, 1256, 1111, 1083, 839, 778 and $704 \mathrm{~cm}^{-1} . \delta_{\mathrm{H}}\left(400 \mathrm{MHz} ; \mathrm{CDCl}_{3}\right): 9.51(1 \mathrm{H}, \mathrm{s}$, aldehyde $\mathrm{CH}), 6.04-6.00(2 \mathrm{H}, \mathrm{m}$, alkene $\mathrm{CH}$ ), 5.71 (2 H, app. dt, $J=10.5,2.0$, alkene $\mathrm{CH}$ ), 3.76 (2 H, s, $\left.\mathrm{CH}_{2} \mathrm{OTBS}\right), 2.74-2.72$ $\left(2 \mathrm{H}, \mathrm{m}\right.$, ring $\left.\mathrm{CH}_{2}\right), 0.86(9 \mathrm{H}, \mathrm{s}, t-\mathrm{Bu})$ and $0.03\left(6 \mathrm{H}, \mathrm{s}, 2 \times \mathrm{CH}_{3}\right) . \delta_{\mathrm{C}}\left(100 \mathrm{MHz} ; \mathrm{CDCl}_{3}\right): 200.9$ (aldehyde $\mathrm{CH}), 128.3(2 \times \mathrm{CH}), 122.7(2 \times \mathrm{CH}), 67.3\left(\mathrm{CH}_{2}\right), 55.3(\mathrm{C}), 27.0\left(\mathrm{CH}_{2}\right), 25.7(3 \times$ $\left.\mathrm{CH}_{3}\right), 18.2(\mathrm{C})$ and $-5.6\left(2 \times \mathrm{CH}_{3}\right)$.

tert-Butyldimethyl[[1-(oxiran-2-yl)cyclohexa-2,5-dienyl]methoxy]silane (10). $n$-Butyllithium (1.75 $\mathrm{ml}$ of a $2.5 \mathrm{M}$ solution in hexanes, $4.37 \mathrm{mmol}$ ) was added to a solution of aldehyde 17 $(1.00 \mathrm{~g}, 3.97 \mathrm{mmol})$ and dibromomethane $(0.42 \mathrm{ml}, 5.95 \mathrm{mmol})$ in THF $(30 \mathrm{ml})$ at $-78{ }^{\circ} \mathrm{C}$. The reaction mixture was warmed to room temperature and stirred for $24 \mathrm{~h}$, before being quenched with saturated aqueous $\mathrm{NH}_{4} \mathrm{Cl}$. The mixture was extracted with ether, the combined extracts being dried $\left(\mathrm{Na}_{2} \mathrm{SO}_{4}\right)$ before the solvent was removed in vacuo affording a crude mixture of aldehyde and epoxide (aldehyde: epoxide 2:7, $1.09 \mathrm{~g}$ ). The aldehyde and epoxide were inseparable by column chromatography, so the crude mixture was re-dissolved in $\mathrm{MeOH}$ (15 ml) and $\mathrm{NaBH}_{4}(75 \mathrm{mg}, 1.98 \mathrm{mmol})$ added to reduce the excess aldehyde. After stirring for $1 \mathrm{~h}$ at room temperature, the reaction was quenched with water and the mixture extracted with ether, the combined extracts being dried $\left(\mathrm{Na}_{2} \mathrm{SO}_{4}\right)$ before the solvent was removed in vacuo. Chromatography on silica gel $\left(\mathrm{Et}_{2} \mathrm{O}\right.$ : petroleum ether 1:49) afforded the title compound 10 (400 mg, 38\%) as a colourless oil. IR: $v_{\max }$ (Neat): 2955, 2929, 2886, 2857, 1471, 1464, 1254, 1106, 1080, 840, 777 and $719 \mathrm{~cm}^{-1}$. NMR $\delta_{\mathrm{H}}\left(400 \mathrm{MHz} ; \mathrm{CDCl}_{3}\right): 5.91-5.83(2 \mathrm{H}, \mathrm{m}$, alkene $\mathrm{CH})$, 5.67 ( $1 \mathrm{H}$, app. dq, $J=10.1,2.0$, alkene $\mathrm{CH}$ ), 5.37 ( $1 \mathrm{H}$, app. dq, $J=10.3,2.0$, alkene $\mathrm{CH}), 3.63$ $\left(1 \mathrm{H}, \mathrm{d}, J=9.3\right.$, one of $\left.\mathrm{CH}_{2} \mathrm{OTBS}\right), 3.48\left(1 \mathrm{H}, \mathrm{d}, J=9.3\right.$, one of $\left.\mathrm{CH}_{2} \mathrm{OTBS}\right), 3.13(1 \mathrm{H}, \mathrm{dd}, J=$ 4.0, 2.9, epoxide $\mathrm{CH}$ ), $2.66-2.64$ (3 H, m, one of epoxide $\mathrm{CH}_{2}$ and ring $\left.\mathrm{CH}_{2}\right), 2.60(1 \mathrm{H}$, dd, $J$ 5.1, 2.9, one of epoxide $\left.\mathrm{CH}_{2}\right), 0.90(9 \mathrm{H}, \mathrm{s}, t-\mathrm{Bu}), 0.05\left(3 \mathrm{H}, \mathrm{s}, \mathrm{CH}_{3}\right)$ and $0.04\left(3 \mathrm{H}, \mathrm{s}, \mathrm{CH}_{3}\right) ; \delta_{\mathrm{C}}$ $\left(100 \mathrm{MHz} ; \mathrm{CDCl}_{3}\right)$ : $127.6(\mathrm{CH}), 126.2(\mathrm{CH}), 126.1(\mathrm{CH}), 124.9(\mathrm{CH}), 68.6\left(\mathrm{CH}_{2}\right), 55.2(\mathrm{CH})$, $44.3\left(\mathrm{CH}_{2}\right), 41.8(\mathrm{C}), 27.0\left(\mathrm{CH}_{2}\right), 25.8\left(3 \times \mathrm{CH}_{3}\right), 18.3(\mathrm{C})$ and $-5.5\left(2 \times \mathrm{CH}_{3}\right)$. MS-APCI: $m / z$ $(\%)=267\left(\mathrm{M}+\mathrm{H}^{+}, 100\right), 249(28), 176(8), 156(13), 132(22)$ and 115 (3). HRMS-APCI: $m / z$ [M $+\mathrm{H}]^{+}$calcd for $\mathrm{C}_{15} \mathrm{H}_{27} \mathrm{O}_{2} \mathrm{Si}$ : 267.1780; found: 267.1771 .

[1-[2-Bromo-1-(tert-butyldimethylsilyloxy)ethyl]cyclohexa-2,5-dienyl]methanol $\quad(23) . \quad t$ Butyllithium $(1.00 \mathrm{ml}$ of $1.7 \mathrm{M}$ solution in pentane, $1.70 \mathrm{mmol}$ ) was added to a solution of bromide 11 (196 mg, $0.850 \mathrm{mmol})$ in THF $(10 \mathrm{ml})$ at $-78{ }^{\circ} \mathrm{C}$. After stirring for 10 minutes epoxide 10 (113 mg, $0.425 \mathrm{mmol}$ ) was added. The resulting solution was stirred for 15 minutes at $-78^{\circ} \mathrm{C}$ before $\mathrm{BF}_{3}$.THF $(0.05 \mathrm{ml}, 0.425 \mathrm{mmol})$ was added. After stirring for an additional $1 \mathrm{~h}$, the reaction was quenched at $-78{ }^{\circ} \mathrm{C}$ with saturated aqueous $\mathrm{NH}_{4} \mathrm{Cl}$ solution. The mixture was extracted with $\mathrm{Et}_{2} \mathrm{O}$, the combined extracts being dried $\left(\mathrm{Na}_{2} \mathrm{SO}_{4}\right)$ before the solvent was removed in vacuo. Chromatography on silica gel $\left(\mathrm{Et}_{2} \mathrm{O}\right.$ : hexane 1:99) afforded the title compound 23 (94 mg, 64\%) as a colourless oil. IR: $v_{\max }$ (Neat): 3478, 3029, 2928, 2857, 1472, 1253, 1106, 837, 777 and $655 \mathrm{~cm}^{-1}$. NMR: $\delta_{\mathrm{H}}\left(400 \mathrm{MHz} ; \mathrm{CDCl}_{3}\right): 5.95-5.86(2 \mathrm{H}, \mathrm{m}$, alkene $\mathrm{CH}), 5.81(1 \mathrm{H}$, 
ddd, $J=10.4,4.0,2.0$, alkene $\mathrm{CH}), 5.43(1 \mathrm{H}$, ddd, $J=10.1,4.1,2.0$, alkene $\mathrm{CH}), 4.01(1 \mathrm{H}$, app. broad d, $J=10.5$, CHOTBS $), 3.72(1 \mathrm{H}, \mathrm{s}, \mathrm{OH}), 3.67\left(1 \mathrm{H}, \mathrm{d}, J=9.5\right.$, one of $\left.\mathrm{CH}_{2} \mathrm{OH}\right), 3.58(1 \mathrm{H}$, d, $J=9.5$, one of $\left.\mathrm{CH}_{2} \mathrm{OH}\right), 3.51\left(1 \mathrm{H}, \mathrm{dd}, J=10.5,1.8\right.$, one of $\left.\mathrm{CH}_{2} \mathrm{Br}\right), 3.26(1 \mathrm{H}, \mathrm{t}, J=10.5$, one of $\left.\mathrm{CH}_{2} \mathrm{Br}\right), 2.68-2.64\left(2 \mathrm{H}, \mathrm{m}\right.$, ring $\left.\mathrm{CH}_{2}\right), 0.89(9 \mathrm{H}, \mathrm{s}, t-\mathrm{Bu})$ and $0.05\left(6 \mathrm{H}, \mathrm{s}, 2 \times \mathrm{CH}_{3}\right) ; \delta_{\mathrm{C}}(100$ $\left.\mathrm{MHz} ; \mathrm{CDCl}_{3}\right): 127.4(\mathrm{CH}), 127.1(\mathrm{CH}), 126.6(\mathrm{CH}), 124.4(\mathrm{CH}), 76.5(\mathrm{CH}), 70.8\left(\mathrm{CH}_{2}\right), 45.2$ (C), $37.9\left(\mathrm{CH}_{2}\right), 27.2\left(\mathrm{CH}_{2}\right), 25.8\left(3 \times \mathrm{CH}_{3}\right), 18.2(\mathrm{C})$ and $-5.6\left(2 \times \mathrm{CH}_{3}\right)$. MS-APCI: $m / z(\%)=$ 349 (100), 347 (M+H' , 94), 331 (27), 329 (24), 217 (53), 215 (50), 199 (34), 197 (35), 158 (6), 156 (13), 132 (18) and 117 (12). HRMS-APCI: $m / z[\mathrm{M}+\mathrm{H}]^{+}$calcd for $\mathrm{C}_{15} \mathrm{H}_{28}{ }^{79} \mathrm{BrO}_{2} \mathrm{Si}$ : 347.1042; found: 347.1030 .

\section{2-Bromo-1-[(1RS,3aSR,7aSR)-1-(2-bromophenyl)-1,3,3a,6,7,7a-hexahydroisobenzofuran-4-} yl]ethanone (18). $t$-Butyllithium ( $1.33 \mathrm{ml}$ of $1.7 \mathrm{M}$ solution in pentane, $2.26 \mathrm{mmol}$ ) was added to a solution of bromide $11(261 \mathrm{mg}, 1.13 \mathrm{mmol})$ in THF $(10 \mathrm{ml})$ at $-78{ }^{\circ} \mathrm{C}$. After stirring for 10 minutes epoxide 10 (155 mg, $0.58 \mathrm{mmol})$ was added. The resulting solution was stirred for 15 minutes at $-78{ }^{\circ} \mathrm{C}$ before $\mathrm{BF}_{3}$.THF $(0.07 \mathrm{ml}, 0.56 \mathrm{mmol})$ was added. After stirring for an additional $1 \mathrm{~h}$, the reaction was quenched at $-78^{\circ} \mathrm{C}$ with saturated aqueous $\mathrm{NH}_{4} \mathrm{Cl}$ solution. The mixture was extracted with $\mathrm{Et}_{2} \mathrm{O}$, the combined extracts being dried $\left(\mathrm{Na}_{2} \mathrm{SO}_{4}\right)$ before the solvent was removed in vacuo. Chromatography on silica gel (Et2O: hexane 1:99) afforded an approximately 1:1 mixture of bromide $\mathbf{1 1}$ and compound $\mathbf{2 3}(157 \mathrm{mg})$ as a colourless oil. Trifluoromethanesulfonic acid $(0.01 \mathrm{ml}, 0.12 \mathrm{mmol})$ was added to a sample of the mixture of compounds 11 and $23(51 \mathrm{mg})$ in $\mathrm{CH}_{2} \mathrm{Cl}_{2}(2 \mathrm{ml})$ at $0{ }^{\circ} \mathrm{C}$. The resulting solution was warmed to room temperature and stirred for 15 minutes before a further portion of trifluoromethanesulfonic acid $(0.01 \mathrm{ml}, 0.12 \mathrm{mmol})$ was added. After stirring for an additional 10 minutes, the reaction was quenched by addition of saturated aqueous $\mathrm{NaHCO}_{3}$ solution. The crude mixture was extracted with $\mathrm{CH}_{2} \mathrm{Cl}_{2}$, the combined extracts being dried ( $\left.\mathrm{Na}_{2} \mathrm{SO}_{4}\right)$ before the solvent was removed in vacuo. Chromatography on silica gel (Et2O: hexane 1:9) afforded the title compound $18(22 \mathrm{mg}, 29 \%)$ as a colourless oil. NMR: $\delta_{\mathrm{H}}\left(400 \mathrm{MHz} ; \mathrm{CDCl}_{3}\right): 7.56-7.51(2 \mathrm{H}, \mathrm{m}$, aryl CH$)$, $7.30(1 \mathrm{H}$, app. td, $J=7.6,1.0$, aryl CH $), 7.13(1 \mathrm{H}$, app. td, $J=7.6,1.6$, aryl CH), $7.07(1 \mathrm{H}$, app. dd, $J=5.3,1.7$, alkene $\mathrm{CH}), 5.31(1 \mathrm{H}, \mathrm{d}, J=4.8$, CHO $), 4.50(1 \mathrm{H}, \mathrm{dd}, J=9.2,8.2$, one of $\left.\mathrm{CH}_{2} \mathrm{O}\right), 4.19\left(2 \mathrm{H}, \mathrm{s}, \mathrm{CH}_{2} \mathrm{Br}\right), 3.63\left(1 \mathrm{H}\right.$, app. dd, $J=9.0,8.3$, one of $\left.\mathrm{CH}_{2} \mathrm{O}\right), 3.49-3.41(1 \mathrm{H}, \mathrm{m}$, ring junction $\mathrm{CH}), 2.80(1 \mathrm{H}$, ddt, $J=13.2,6.6,4.8$, ring junction $\mathrm{CH}), 2.32(1 \mathrm{H}$, dtd, $J=19.7$, 5.4, 2.0, one of allylic $\left.\mathrm{CH}_{2}\right), 2.24-2.14\left(1 \mathrm{H}\right.$, broad m, one of allylic $\left.\mathrm{CH}_{2}\right), 1.08(1 \mathrm{H}$, app, ddd, $J=24.9,13.2,5.2$, one of $\left.\mathrm{CH}_{2}\right)$ and $0.90-0.82\left(1 \mathrm{H}, \mathrm{m}\right.$, one of $\left.\mathrm{CH}_{2}\right) ; \delta_{\mathrm{C}}\left(100 \mathrm{MHz} ; \mathrm{CDCl}_{3}\right)$ : $192.1(\mathrm{C}=\mathrm{O}), 143.6$ (alkene $\mathrm{CH}), 138.7(\mathrm{C}), 137.3(\mathrm{C}), 132.3(\mathrm{CH}), 128.6(\mathrm{CH}), 128.2(\mathrm{CH})$, 127.0 (CH), $121.3(\mathrm{C}), 82.8(\mathrm{CH}), 72.0\left(\mathrm{CH}_{2}\right), 38.4(\mathrm{CH}), 38.3(\mathrm{CH}), 29.7\left(\mathrm{CH}_{2}\right), 25.8\left(\mathrm{CH}_{2}\right)$ and $19.2\left(\mathrm{CH}_{2}\right)$. MS-APCI: $m / z(\%)=403(48), 401(100), 399\left(\mathrm{M}+\mathrm{H}^{+}, 52\right), 385(33), 383(65), 381$ (34) and 219 (34). HRMS-APCI: $m / z[\mathrm{M}+1]^{+}$calcd for $\mathrm{C}_{16} \mathrm{H}_{17}{ }^{79} \mathrm{Br}_{2} \mathrm{O}_{2}$ : 398.9595; found: 398.9585 . 


\section{Acknowledgements}

We are grateful to the EPSRC and AstraZeneca for financial support.

\section{References}

1. (a) Elliott, M. C.; El Sayed, N. N. E.; Paine, J. S. Eur. J. Org. Chem. 2007, 792. (b) Butters, M; Elliott, M. C.; Hill-Cousins, J.; Paine, J. S.; Westwood, A. W. J. Tetrahedron Lett. 2008, 49, 4446.

2. (a) Overman, L. E.; Pennington, L. D. Org. Lett. 2000, 2, 2683. (b) MacMillan, D. W. C.; Overman, L. E. J. Am. Chem. Soc. 1995, 117, 10391. (c) MacMillan, D. W. C.; Overman, L. E.; Pennington, L. D. J. Am. Chem. Soc. 2001, 123, 9033. (d) Molander, G. A.; Jeffrey, S. C. Tetrahedron Lett. 2002, 43, 359. (e) Kim, H.; Lee, H.; Kim, J.; Kim, S.; Kim, D. J. Am. Chem. Soc. 2006, 128, 15851.

3. Chan, T. H.; Brook, M. A.; Chaly, T. Synthesis 1983, 203.

4. For examples see: (a) Peters, U.; Bankova, W.; Welzel, P. Tetrahedron 1987, 43, 3803. (b) Wuts, P. G. M.; Bigelow, S. S. J. Org. Chem. 1988, 53, 5023. (c) Mulzer, J.; Schollhorn, B. Angew. Chem. Int. Ed. 1990, 29, 431. (d) Molander, G. A.; Swallow, S. J. Org. Chem., 1994, $59,7148$.

5. Melchart, M.; Habtemariam, A.; Novakova, O.; Moggach, S. A.; Fabbiani, F. P. A.; Parsons, S.; Brabec, V.; Sadler, P. J. Inorg. Chem. 2007, 46, 8950.

6. Honma, M.; Nakada, M. Tetrahedron Lett. 2003, 44, 9007. 